\title{
February 2012 Workshop Jumpstarts the Mekong Fish Monitoring Network
}

\section{The Backdrop}

The Mekong River in Southeast Asia (fig. 1) travels through a basin rich in natural resources. The river originates on the northern slope of the world's tallest mountains, the Himalaya Range (Campbell, 2009), and then drops elevation quickly through steep mountain gorges (fig. 2), tumbling out of China into Myanmar (Burma) and the Lao People's Democratic Republic (Lao PDR). The precipitous terrain of Lao PDR and Thailand generates interest in the river and its tributaries for hydropower development (Dugan and others, 2010; Ferguson and others, 2011). The terrain, soils, water, and climate make it one of the world's most biologically rich regions (Woodruff, 2010). The Mekong's bounty is again on display in the Mekong River Delta, where rice production has successfully been increased to high levels making Vietnam second only to Thailand as the world's largest rice exporters (Nielsen, 2003; Niimi and others, 2004; Sakamoto and others, 2009).

At least 800 fish species (Mekong River Commission, 2003; Hortle, 2009; Valbo-Jørgensen and others, 2009; Ziv and others, 2011) contribute to the natural resource bounty of the Mekong River and are the basis for one of the world's most productive fisheries (Hortle, 2007; Baran and Myschowoda, 2009) that provide the primary protein source to more than 50 million people (Hortle, 2009). Different and creative types of fishing gear deployed include the lii trap fishery in Lao PDR, the dai net fishery on the Tonlé Sap River in Cambodia (fig. 3), and various types of

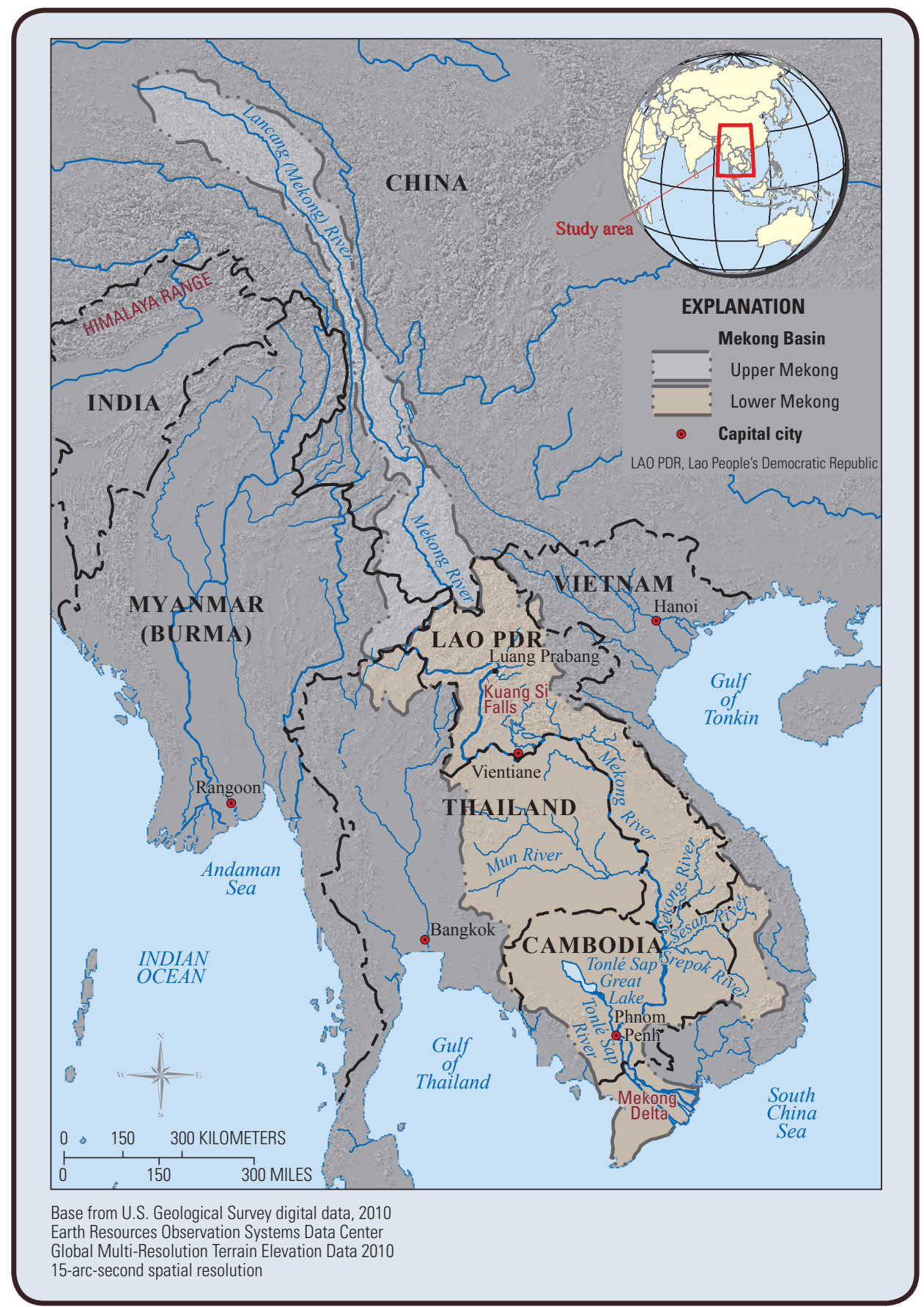

Figure 1. The upper and lower basins and tributaries of the Mekong River in Southeast Asia. 


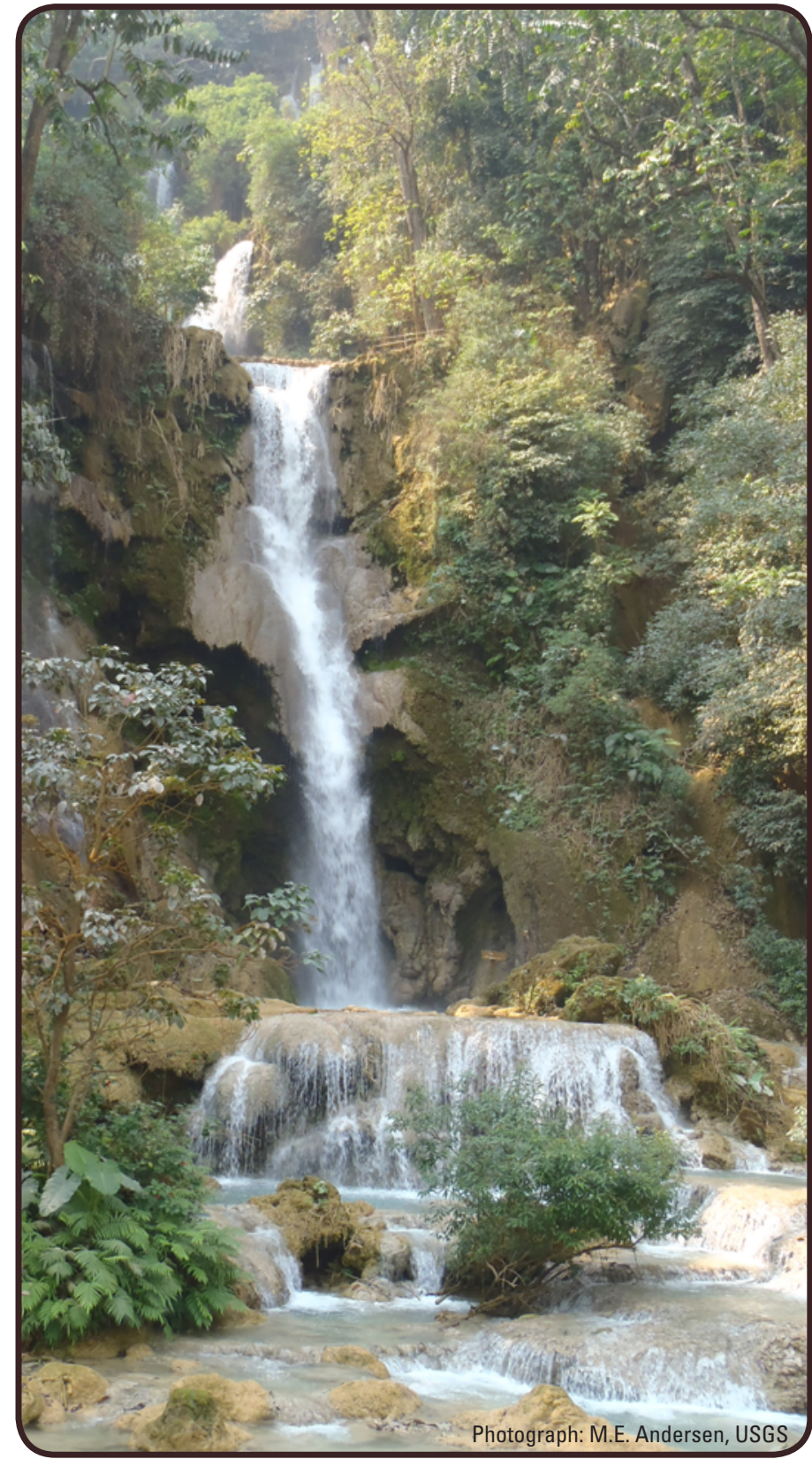

Figure 2. Kuang Si (Kouangxi) Falls, located close to the city of Luang Prabang, Lao People's Democratic Republic, arise from springs that feed the Mekong River.

fisheries on the Tonlé Sap Great Lake in Cambodia and in the Mekong River Delta in Vietnam.

Though there are some capture fisheries on the river in the Yunnan Province of China farther upstream, it is in Lao PDR and, especially, farther downstream into Thailand, Cambodia, and Vietnam that people increasingly capitalize on the river's abundance of fishes as a source of protein (Baran and Myschowoda, 2009; Hortle, 2009) (fig. 4). Baran and Myschowoda (2009) estimated that 1 percent of the river's fishery occurs in Yunnan Province and 7 percent in Lao PDR, compared with 35,25 , and 32 percent of the fishery being conducted in Thailand, Cambodia, and Vietnam, respectively (these authors did not include Myanmar in their estimate).

Against this backdrop of rich natural resources, the U.S. Geological Survey (USGS) is working with the consulting firm FISHBIO, colleagues from the international Delta Research and
Global Observation Network (DRAGON) Institute, and a broad contingent of Southeast Asian representatives and partners from abroad to increase knowledge of the Mekong River fisheries and to develop the capacity of permanent residents to investigate and understand these fisheries resources. With the LMB region facing the likelihood of significant environmental changes as a result of both human activities and global climate change, enhancing environmental understanding is critical (Baran and Myschowoda, 2009).

\section{The Workshop}

To encourage cooperation among the LMB scientists and managers in the study of the Mekong River's fisheries, FISHBIO and the USGS - with generous support from the U.S. State Department - hosted a workshop in Phnom Penh, Cambodia, in February 2012. Workshop participants were from Lao PDR, Thailand, Cambodia, and Vietnam. Representatives from the governments, universities, nongovernmental organizations

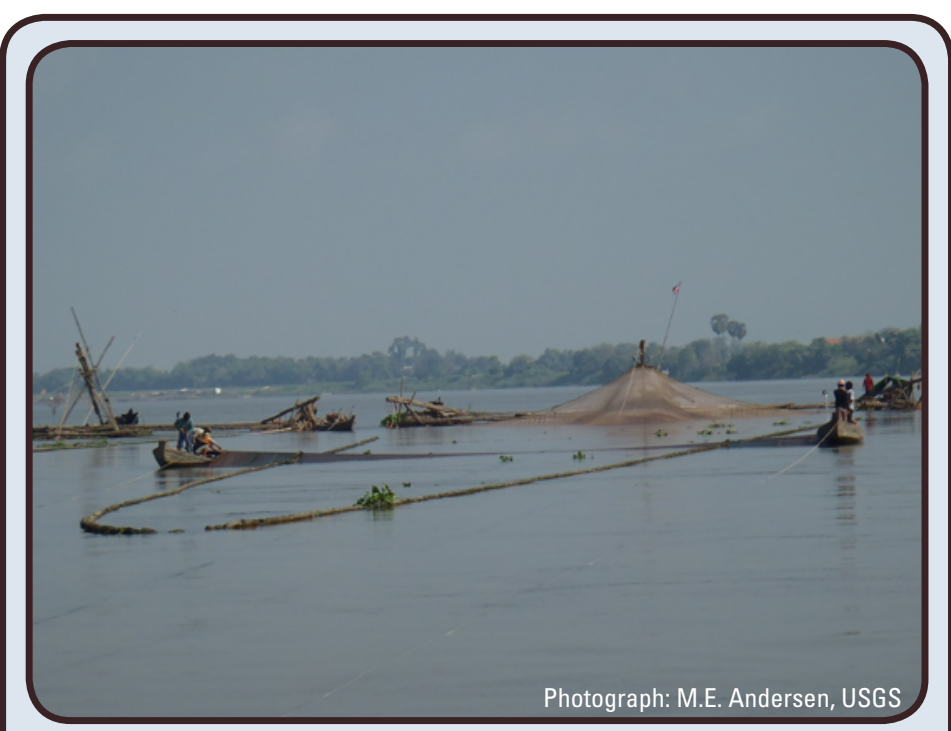

Figure 3. Fishers gathering their diverse catch from the large dai net fishery on the Tonlé Sap River, Cambodia.

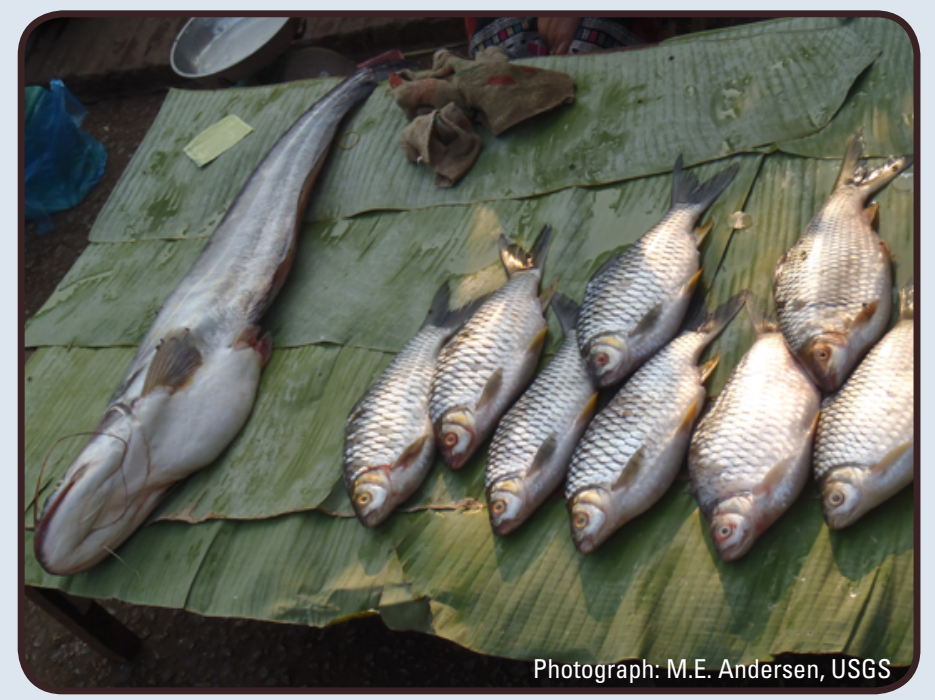

Figure 4. Mekong River catch offered for sale at the morning market in Luang Prabang, Lao People's Democratic Republic. The single large fish on left is likely Wallago attu, and the smaller fish on the right are likely Henicorhynchus siamensis. 
(NGOs), and the Mekong River Commission discussed current and potential methods and mechanisms of the Mekong Fish Monitoring Network (hereafter, the Network) (fig. 5).

The goals of the workshop were to determine if the Network and associated databases were of interest and value to the LMB nations, to determine if future fisheries monitoring data would be comparable among the nations, and to establish methods and an organizational structure for collaborating on future monitoring and research. The first day of the 2-day workshop began with presentations by USGS personnel demonstrating examples of Web-accessible databases, data analyses, fish tracking, and spatial visualizations that LMB scientists could employ to support the Network. The next presentations of the workshop were delivered by representatives from government fisheries agencies, universities, and NGOs

\section{Participants in the Mekong Fish Monitoring Network Workshop, February 9 and 10, 2012}

- Cambodian Molecular Genetics Group

- Can Tho University - Vietnam

- Conservation International

- Department of Fisheries - Thailand

- Department of Livestock and Fisheries - Lao PDR

- Fisheries Action Coalition Team - Cambodia

- Fisheries Administration - Cambodia

- Inland Fisheries Research and Development Institute Cambodia

- International Union for Conservation of Nature - Cambodia

- Living Aquatic Resources Research Center - Lao PDR

- Mekong River Commission

- National University of Laos

- Royal University of Agriculture - Cambodia

- Scientific Capacity Development Initiative

- Ubon Ratchathani University - Thailand

- Vietnam Institute of Fisheries Economics and Planning

- Wildlife Conservation Society

- World Wildlife Fund

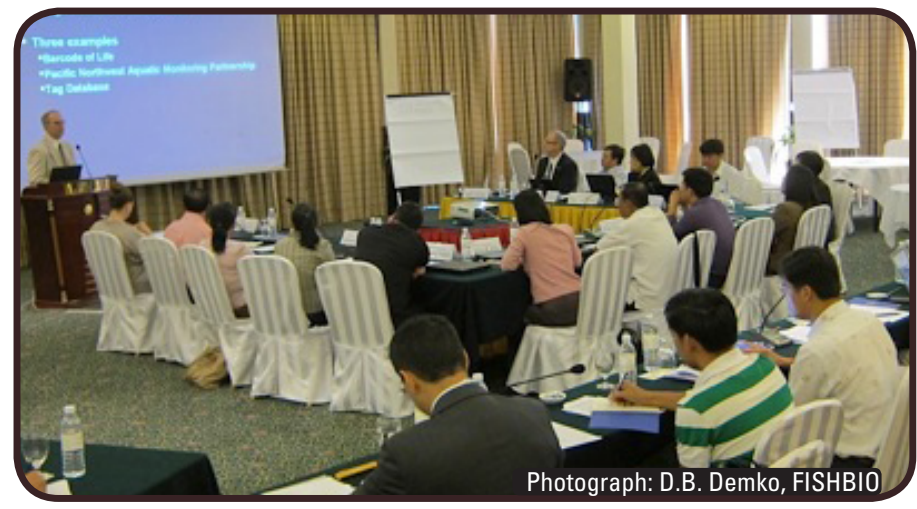

Figure 5. February 2012 workshop of the Mekong Fish Monitoring Network in Phnom Penh, Cambodia. of each of the four LMB nations describing their current and future monitoring and research activities. For the remainder of the workshop the attendees participated in smaller group discussions (fig. 6) regarding the specifics of researching fisheries in the LMB. The groups reconvened periodically to share their responses with the other participants.

\section{The Network}

In the 1990s and the first decade of the 2000s, many fish studies were conducted in the LMB (Hortle, 2009), but the limited means available to individual researchers for sharing their protocols and data inhibited effective communication among those researchers, resource managers, and decisionmakers in the region. A network of researchers collecting comparable data would allow for more robust analyses of LMB fish populations, thereby supporting projections of how these populations may respond to future environmental challenges (Baran and Myschowoda, 2009). The Network would increase the capacity of local researchers and institutions to further develop the tools to assess their fisheries themselves. The Internet-linked Network would be a highly accessible forum for idea exchange, data archiving, and general information.

\section{Current Activities and Future Plans}

The USGS and FISHBIO are currently preparing a detailed workshop report including the specific responses to discussion questions posed to the small discussion groups. Example questions include:

- What are the most important fisheries questions you are interested in answering?

- What resources (equipment, personnel, training, or other) are needed for your organization to participate in a monitoring network?

- Before your organization can consider sharing fisheries data, what logistics, costs, staff, training, policies, or other considerations must be addressed?

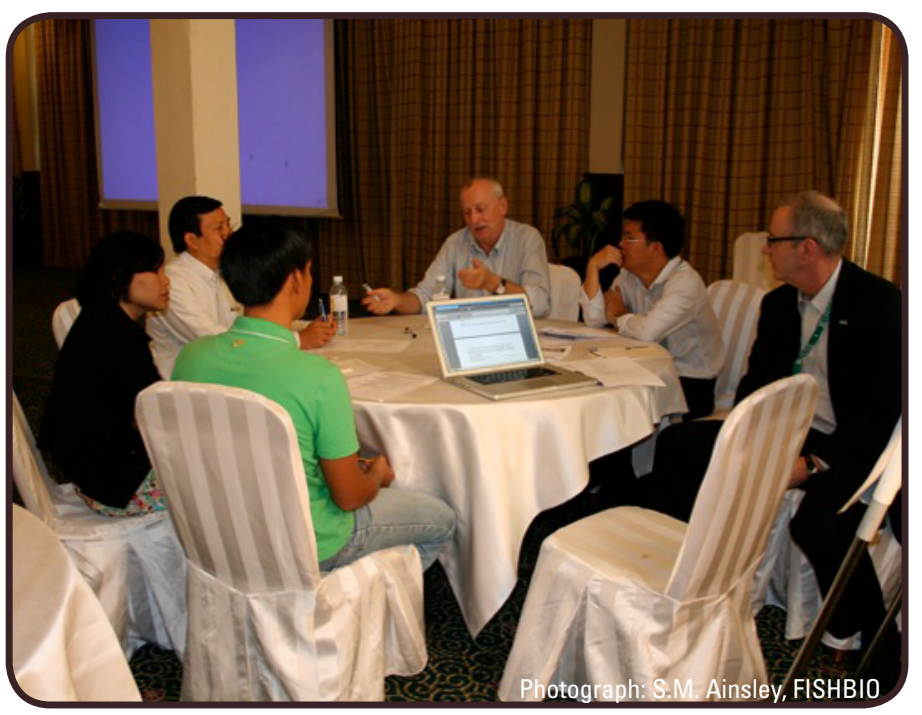

Figure 6. More than half of the time spent by participants in the Phnom Penh, Cambodia, workshop in February 2012 occurred in small, productive group-discussion sessions. 
Two pilot projects will be used to field-test data-collection and data-entry protocols for the Network. These projects will be led by FISHBIO in Lao PDR (sponsored by FISHBIO and Lao PDR's Department of Livestock and Fisheries) and by Can Tho University in Vietnam (sponsored by Can Tho University, the U.S. State Department, and the USGS) (fig. 7). Further, the USGS is developing a database for uploading the data generated by these pilot studies. This database is being designed to accommodate both historical and future data. The pilot projects will demonstrate the Network functions and will also serve as models to support the development of additional funding proposals.

The participants in this international workshop agreed that the Mekong Fish Monitoring Network would be useful but would require additional funding to secure their full participation. The USGS and FISHBIO are collaboratively seeking additional funding to expand research participation and projects in all four LMB nations. If the Network can facilitate cooperation among many fisheries researchers in the LMB, the basin would become a model of cooperative international fishery studies and would increase the understanding of a river basin rich in natural resources.

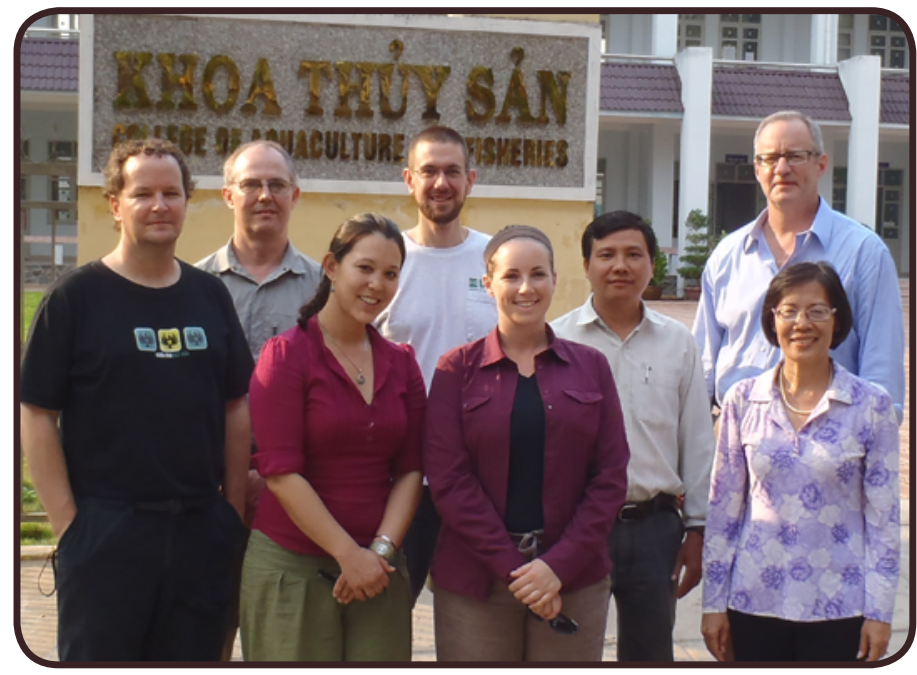

Figure 7. Mekong Fish Monitoring Network pilot project participants for 2012 representing Can Tho University, FISHBIO, and the U.S. Geological Survey.

\section{References Cited}

Baran, E., and Myschowoda, C., 2009, Dams and fisheries in the Mekong Basin: Aquatic Ecosystem Health and Management, v. 12, no. 3, p. 227-234, accessed April 2012 at http://dx.doi.org/10.1080/14634980903149902.

Campbell, I.C., 2009, Introduction, in Campbell, I.C., ed., The Mekong-Biophysical environment of an international river basin: New York, Academic Press, Elsevier, p. 1-11.

Dugan, P.J., Barlow, C., Agostinho, A.A., Baran, E., Cada, G.F., Chen, D., Cowx, I.G., Ferguson, J.W., Jutagate, T., MallenCooper, M., Marmulla, G., Nestler, J., Petrere, M., Welcomme, R.L., and Winemiller, K.O., 2010, Fish migration, dams, and loss of ecosystem services in the Mekong Basin: Ambio, v. 39, p. 344-348.
Ferguson, J.W., Healy, M., Dugan, P., and Barlow, C., 2011, Potential effects of dams on migratory fish in the Mekong River-Lessons from salmon in the Fraser and Columbia Rivers: Environmental Management, v. 47, p. 141-159.

Hortle, K., 2007, Consumption and yield of fish and other aquatic animals from the Lower Mekong Basin: Vientiane, Lao PDR, Mekong River Commission technical paper no. 16, 87 p.

Hortle, K.G., 2009, Fisheries of the Mekong River Basin, in Campbell, I.C., ed., The Mekong-Biophysical environment of an international river basin: New York, Academic Press, Elsevier, p. 197-247.

Mekong River Commission, 2003, Mekong fish database: Vientiane, Lao PDR, Mekong River Commission Secretariat.

Nielsen, C.P., 2003 Vietnam's rice policy-Recent reforms and future opportunities: Asian Economic Journal, v. 17, no. 1 , p. 1-26.

Niimi, Y., Vasudeva-Dutta, P., and Winters, L.A., 2004, Storm in a rice bowl-Rice reform and poverty in Vietnam in the 1990s: Journal of the Asia Pacific Economy, v. 9, no. 2, p. 170-190.

Sakamoto, T., Phung, C.V., Kotera, A., Jguyen, K.D., and Yokozawa, M., 2009, Analysis of rapid expansion on inland aquaculture and triple rice-cropping areas in a coastal area of the Vietnamese Mekong Delta using MODIS time-series imagery: Landscape and Urban Planning, v. 92, no. 1, p. 34-46.

Valbo-Jørgensen, J., Coates, D., and Hortle, K., 2009, Fish diversity in the Mekong River Basin, in Campbell, I.C., ed., The Mekong - Biophysical environment of an international river basin: New York, Academic Press, Elsevier, p. 161-196.

Woodruff, D.S., 2010, Biogeography and conservation in Southeast Asia-How 2.7 million years of repeated environmental fluctuations affect today's patterns and the future of the remaining refugial-phase biodiversity: Biodiversity and Conservation, v. 19, p. 919-941.

Ziv, G., Baran, E., Nam, S., Rodriguez-Iturbe, I., and Levin, S.A., 2011, Trading-off fish biodiversity, food security, and hydropower in the Mekong River Basin: Proceedings of the National Academy of Sciences Early Edition, accessed April 2012 at www.pnas.org/cgi/doi/10.1073/pnas.1201423109, 6 p.

-Matthew E. Andersen ${ }^{1}$ and Shaara M. Ainsley ${ }^{2}$

\section{For more information, contact}

Director, National Wetlands Research Center

U.S. Geological Survey

700 Cajundome Blvd.

Lafayette, LA 70506

nwrcdirector@usgs.gov

http://www.nwrc.usgs.gov/

Publishing support provided by

Lafayette Publishing Service Center

${ }^{1}$ U.S. Geological Survey.

${ }^{2}$ FISHBIO, Oakdale, Calif. 